\title{
Technológia, elidegenedés és szabadság
}

A tudomány és a technika, miközben olyan közvetítő, amely rendkívüli mértékben megnöveli az emberi megismerés és cselekvés hatékonyságát, egyszersmind ellehetetleníti ember és világa egységének megélését. Vajon lehetséges-e egy új szintézis: cikkében Talbott erre a kérdésre ad végső soron optimista választ. Közelítésmódja éppúgy, mint végkövetkeztetése vitára jó alapot kínál - a kapcsolódó három cikk szerzőjének is.

\section{Szerzői információ:}

Steve Talbott

A Ghenti Természettudományi Intézet kutatásvezetôje. A NetFuture (www.netfuture.org) címû hírlevél kiadója, valamint A jövố nem a számítógép: hogyan múljuk felül a gépeket? (The Future Does Not Computer: Transcending the Machines in Our Midst. Sebastopol, California: O'Reilly \& Associates, 1995.) címủ könyv szerzôje.

Így hivatkozzon erre a cikkre:

Talbott, Steve. „Technológia, elidegenedés és szabadság”.

Információs Társadalom II, 4. szám (2002): 142-149.

A folyóiratban közölt müvek

a Creative Commons Nevezd meg! - Ne add el! - Így add tovább! 4.0 


\section{Steve Talbott Technológia, elidegenedés és szabadság}

Már sokat beszéltem az évek során az absztrakció természetéről, mely gépek uralta korunkat jellemzi. Az „absztrakción” tulajdonképpen a világról szerzett tapasztalataink elsorvadását értem. Hajlamosakká váltunk lebecsülni a világ kifejezô, érzékletes, minőségi aspektusait, a precíz, mérhetô, hatékonyan manipulálható vonások javára (amik egyben a mechanikai aspektusok), amelyeket „absztrahálunk", kivonunk egy teljesebb valóságból. Az eredmény a természet egyfajta természetietlenné tétele, a világ „gépi állapotok” sorozataként való újraértelmezése lett. És az a hajlamunk, hogy egyre absztraktabb módon, egyfajta szoftverként fogjuk fel e gépi állapotokat, testi valónk elhagyását látszik sürgetni.

Utaltam már például (NetFuture 84) a kémikusra, aki ahelyett, hogy évente néhány tucat új anyagot hozna létre, most ötven- vagy százezret szintetizál. De ezek a vegyszerek, melyeket mikroszkopikus mennyiségben állítanak elő, és kifinomult laboratóriumi mûszerekkel analizálnak, nem részei a kémikus érzéki tapasztalatának; elsôsorban adatok halmazaként léteznek számítógépes adatbázisokban - olyan adatbázisokban, melyek akár anyagok millióit „tartalmazzák”. Az anyagi világról szerzett ismereteink egyre kevésbé kapcsolódnak a közvetlen tapasztalathoz, és egyre inkább a gépi elemzés, kalkuláció és következtetés függvényei.

Hasonlóan, az elszigetelt traktorkabinban magasan a talaj fölött suhanó gazdálkodó, aki maga mögött húzza GPS vezérlésű felszerelését, melynek szoftverje gazdaságosan beosztja a mútrágyát a többhektáros birtokon, nem éppen „természethez közeli életet él".

Aztán ott a szomszéd gazda, aki csirkét tart - mindegyik csőrtelenítve, vegyszerekkel teletömve, életét egy-két arasznyi területen élheti, megfosztva minden természetes késztetése kielégítésétôl a felfedezés, kapirgálás és csipegetés területén. Ez a gazdálkodó csak azért tudja tolerálni saját kegyetlenségét, mert az állatok láthatatlanok számára. Eltûnnek a gyár bevételeivel és kiadásaival kapcsolatos absztrakt számlákkal való hatékony egyensúlyozás leple mögött.

És újfent utalnom kell arra, hogy a termelố üzemek elválasztják a munkásokat az anyagtól, amivel dolgoznak. Szoftver-vezérlésú plazmaágyúk formálják a fémet csendben, füstmentesen, láthatatlanul. A számítógépes program absztrakt mintái múködtetik a plazmaágyút, mely cserébe reprodukálja ezt a mintát magán a fémen - mindez anélkül megy végbe, hogy valakinek vagy valamiféle gépnek észrevétlenül bele kéne avatkoznia. Csak egy pár absztrakciót manipulálunk a képernyôn, és aztán rejtett, precízen irányított erôk automatikusan újrarendezik a világ szövetét - a fém megmunkálódik, a DNS spirál megszakad, a kis dobozokban élő csirkék táplálékhoz jutnak, a bomba becsapódik több száz kilométerrel odébb. Mindeközben csodálatosan hatékony manipuláció zajlik - s már nincs közvetlen kapcsolatunk azzal, amit manipulálunk (vagy megölünk). Életünk az absztrakciók hálóján való navigáció. 
Végezetül, már többször hangsúlyoztam, milyen veszedelmes lehet az emberi viszonyokra ez az absztrakció és világvesztés, még ha elismerjük is, hogy absztrakciós képességünk nagyon is megfelel nagy céljainknak. Ahhoz, hogy e nagy célt megvilágítsam, elôször az absztrakcióhoz vezetổ történelmi folyamatot kell összefoglalnom a legtömörebb formában és a legszélesebb általánosításokkal.

\section{Matematikai idő}

Az óra XIII. századi feltalálásáig a tartam és a ritmus organikus jellegú volt. A nappalok és éjjelek hossza váltakozott az év folyamán, a gazdálkodók a vetéshez és aratáshoz viszonyítva mérték az időt, és az emberi tüdő és szív hangulattól és tevékenységtôl függôen változó ritmusai segítettek az idô fogalmának értelmezésében.

De az óra, ahogy arra Lewis Mumford figyelmeztet, „az emberi eseményektôl elválasztotta az idôt, és elősegítette annak a hitnek a kialakulását, hogy létezik a matematikailag mérhetô intervallumok független világa" (Mumford, 1963, 15. o.). Ma nem akkor eszünk, amikor éhesek vagyunk, hanem amikorra az étkezés be lett ütemezve, és nem akkor alszunk, amikor elfáradunk, hanem amikor eljön a lefekvés ideje. Neil Postman szavaival „Megtanultuk közömbösen nézni a Napot és az évszakokat, egy másodpercekből és percekből álló világ érdekében a természet tekintélyét is felülbíráljuk" (Postman, 1986, 11. o.).

Tehát az idổ azonos pillanatok egységes idô-vonalává válik. Éppígy többé már nem vagyunk hozzákötve az összefüggô események szorosan szốtt hálózatához, hanem kívül állunk az időpillanatok most már mérhető sorozatán, megfigyelve azokat. Ahelyett, hogy magával ragadna a dolgok időbeli sodrása, olyan objektív „erôforrásokká" alakítjuk át az idő pillanatait, melyeket szabadon használhatunk fel erre vagy arra. Ez elősegíti a leválást és elkülönülést, a jelentés elvesztésének következményével. Mi már nem élünk a „jelenben”, minőségileg részt véve benne; hanem a szolgálatunkba állítjuk.

\section{Matematikai tér}

Ahogy egy egységes matematikai idôre tettünk szert, éppúgy egy egységes matematikai térre is. A változás kézzelfogható a művészi technikák fejlődésében. A lineáris perspektíva reneszánsz kori kifejlốdése elốtt, a tér nem jelent meg a múvésznek önmagában, tárgyaktól függetlenül; sokkal inkább olyan volt, mint a dolgok minőségileg változó ,jelenléte”, s helyi alakját belőlük nyerte. A tér e plasztikus természete, ami megannyi középkori képen nyilvánvaló, tipikusan teljesen összezavarodottnak tûnik számunkra.

Még mindig ízelítőt kaphatunk ebből a korábbi állapotból, ha figyelmünket az Én-Te térre vetjük. A távolság itt is képlékeny mennyiség, ami az interakcióink természete és minôsége függvényében változik. Egy nagy, zsúfolt termet átszelő szemkontaktuson keresztül akár egy másik ember közvetlen közelében érezhetem magam. A tér kettônk között összezsugorodik. Vagy másként fogalmazva, e másik személy

\footnotetext{
A NetFuture 84. száma a http://www.netfuture.org/1999/Feb0999_84.html címen érhetố el - a szerk.
} 
most maga körül, mint fókuszpont körül létrehozza a kölcsönhatás egy sokkal nagyobb és intenzívebb mezejét.

De a reneszánsz és a tudományos forradalom időszakában a dolgok tér-meghatározó minôsége elkezdett eltûnni, átengedve helyét egy passzív, egységes, konténerszerû médiumnak.

„Elôször a tér jön létre, majd az ábrázolt világ szilárd tárgyai helyet kapnak benne az általa diktált szabályoknak megfelelôen. A tér tartalmazza a tárgyakat, amelyek által az [korábban] létre lett hozva. ...Az eredmény egy végtelen, matematikailag homogén tér megközelítése" (White, 1972: 123-24. o.).

A világról szerzett tapasztalatunk megváltozott. A dolgok többé már nem nyúltak felénk és ragadtak meg minket; többé már nem határoztak meg egy burokszerú teret saját minôségeik ereje folytán. Most ott ültek élettelenül, nem az egyedi jellemzô vonásaikkal töltve ki a tér szabályosságát, hanem egyedül matematikai dimenziójuknál fogva.

Így beláthatjuk, hogy ahol valaha az események természetes folyamatába és a jelentés egy térbeli hálójába voltunk beágyazva, most egy olyan önmagunkon „kívüli” tárgyiasított térrel és idôvel találjuk magunkat szemközt, mellyel nincs természetes kapcsolatunk. Ennek az állapotnak egyik neve az „elidegenedés”. De, ahogy rövidesen látni fogjuk, másik neve is van.

\section{Média és kommunikáció}

A könyvnyomtatás XV. századi eljövetelét kommentálva Mumford megjegyzi: „a nyomtatott könyv megszabadította az embereket a közvetlen és a helyi dominanciájától. (...) a nyomtatott nagyobb hatást gyakorolt, mint a tényleges esemény. (...) Létezni azt jelentette, nyomtatásban létezni: a világ többi része fokozatosan háttérbe szorult."

Sokkal késôbb, a XIX. században, a telegráf végül megszabadította a kommunikáló embereket a fizikai helyváltoztatás még meglévố korlátjától (Postman, 1986). Ettől fogva szörfözhettünk az olyan - kontextustól különvált - információ tengerének habzó hullámain, amely alig áll kapcsolatban az emberekkel, közösségekkel, és a hellyel, ahol élünk. A televízió híradója, különböző egybekezdéses „sztorijai” özönével illusztrálja azt, hogyan vált információs környezetünk töredékessé és inkoherensé, lerohanva minket elszigetelt és önkényes információtöredékekkel, melyek életünkre nézve jórészt teljesen irrelevánsak. A hírek nézôivé váltunk, mintsem résztvevôivé.

\section{De váriunk csak egy percet}

Mindezek mögött azt látjuk, hogy az emberiség messzire elrugaszkodott a környezố világhoz fưzôdő organikus kapcsolatától. Egyre inkább a tiszta absztrakciók - a karórák időegységei, a térképek helymeghatározásai, az információ bitjei - birodalmában kíván élni, megtisztulva az anyagi létezés „zúrös” fogalmaitól. 
Legalábbis így is ábrázolhatjuk az absztrakció kifejlődő szokásait és a nyilvánvaló törekvésünket a testtől való leválás felé. Ez egy olyan kép, mely finomítására magam is sok energiát fordítottam - kidolgozva mindazokat a negatív konnotációkat, amelyek a fenti leírásomban is szerepeltek. A negatív képet igazolja az, hogy még fel kell ismernünk, hogy az uralkodó tendenciák egyoldalúsága például, a dolgok minôségének figyelmen kívül hagyása, és a szúklátókörû ragaszkodásunk a testi létezésünktől való elszakadáshoz bizonyos helyeken és közösségekben - mennyire fenyeget minket katasztrófával.

De ugyanakkor, nem gyổzhetjük le ezt az egyoldalúságot anélkül, hogy felismernénk a jelenlegi helyzetünk által nyújtott pozitív lehetôségeket is. Minden egyoldalúság megadja annak lehetőségét, hogy felfedezzük az ellentétes oldalt is. És így most szeretnék egy talán váratlan fordulatot tenni. Ünnepelni fogom az absztrakciót és a technológiát.

\section{Egy kis távolságra van szükségünk}

Gondoljunk újra a televízió híradójára és tegyük fel a kérdést: hogy is lehetne ez másképpen? Hogyan lehetne minden hír teljesen beágyazva életünk közvetlenségébe, koherens mintájába? Egyrészt semmit sem tehetünk az ellen, hogy a teljes bolygó lakóivá váljunk. „Muszáj” odafigyelnünk arra, mi zajlik máshol. De másrészrôl lehetetlen lenne ugyanolyan figyelmet szentelni, és ugyanolyan mély beleérzéssel figyelni mindazt a rengeteg megrendítố és megrázó eseményt többszázezer különbözố közösségben. Ha megpróbálnánk, túláradnának benyomásaink, s még saját közösségünk számára is haszontalanokká válnánk.

Tehát miközben egy bizonyos globális tudatosságra kell törekednünk, úgy látszik, hogy a magunk és a számtalan világbeli történés közé állított absztrakt távolság elkerülhetetlen. E távolság egyik következménye az, hogy „szabadon” megválaszthatjuk a külvilághoz füzôdô kapcsolatainkat, és beleszôhetjük ôket a jelentés nekünk megfelelő szövetébe. Már nincs jogunk panaszkodni amiatt, hogy a koherencia és a jelentés nem csak a hagyományos társadalmi és természeti környezetünkből „adottak” számunkra. A modern egyéniség megszületése magával vonja a jelentés megteremtésében való aktív részvétel felelôsségét.

És azt gondolom, ez az absztrakció alapvetô történelmi funkciója. Segítségével elnyertük szabadságunkat. Igen, amint az emberiség függetlenné válik a világtól, azt kockáztatja, hogy saját elkülönítố absztrakciói fátylába gabalyodik; de egyúttal meg is szabadul a világ kényszerítô erejétôl. Mikor a dolgok jelentése kinyúlik felénk és megragad minket; mikor a környezetünkhöz annyira közvetlenül hozzákapcsolódunk, hogy reakcióink kívülrôl lesznek meghatározottak; mikor az, amit a dolgokról gondolnunk kell, már eleve adott a minôségileg fölénk hatalmasodó érzékelésük folyamán nem vagyunk szabadok. 


\section{A játék számára fenntartołt belső tér}

Maurice Merleau-Ponty beszél erről a nem szabad közvetlenségrôl az erőteljes gesztusokkal kapcsolatban. Egy dühös vagy fenyegetô gesztus „nem a haragra tereli gondolataimat, hanem az maga a harag". Ahogy David Abram továbbgondolta:

„Nem úgy van, hogy először meglátjuk a gesztust, mint egy üres viselkedést, amit ezután összekötünk egy bizonyos tartalommal vagy jelentôsséggel; inkább, a testi gesztus közvetlenül a testünkhöz szól, és ezért bármiféle belsô reflexió nélkül is érthető" (Abram 1996, 74. o.).

Ez igaz és fontos. De az is igaz, hogy a belső reflexió és az alternatív értelmezések tere az a tér, ahol szabadok vagyunk. Ez az, ahol a gesztus maga nem kényszeríti ránk az értelmezési reakciónkat. („Ja, értem már. Ó mérges, de ez esetben mindez nem annyira a saját haragja, mint inkább egy megfontolt erőfeszítés arra, hogy egy agresszortól védje meg gyermekét.") Persze, ebben a reflektáló térben ma már tévesen is gondolkodhatunk dolgokról, ami elképzelhetetlen volt a megelőző korokban. Kiagyalhatunk hazugságokat is. De a tévedés és kétértelműség lehetősége a szabadság részét képezi. Az egymást kiegészítố lehetôség állandóan különbözố perspektívákból láttatja a világot, mindegyikből a maga valóságával.

Owen Barfield a szabadság felé való elmozdulás szép képét nyújtja, mikor arról beszél, hogyan hoztuk le a matematikát az egekbôl, elnyerve a független képességet arra, hogy ,játszunk” az egyenleteinkkel (ahogy a matematikusok szokták mondani) és aztán megtanultuk a matematikai kreációinkat visszahelyezni az egekbe:

„Túlságosan csábító lenne elképzelnünk, hogy néhány ember gondolataiban kirajzolódva a csillagok relatív helyzete és mozgása fokozatosan egyre függetlenebb életet fejlesztett ki magának, mígnem először a trigonometria, majd az algebra európai felemelkedésével teljesen leválasztották önmagukat a külvilágtól? És aztán egy pár kiválóság - mint Kopernikusz, Kepler, Galilei, és Newton - segítségével ez az absztrakt matematika vissza lett helyezve a csillagokhoz, ahonnan származott, és ennek eredményeképp létrejött a végtelen tér kozmogóniája és egy apró föld, amit képzeletünk ma bebarangol?" (Barfield, 1986, 130. o.)

És hozzátehetem, fokozott szabadsággal barangolja be. Szabadsággal arra, hogy új hipotéziseket állítson fel, hogy a dolgokat friss, korában elképzelhetetlen perspektívákból láthassa, sốt hogy tekintetbe vegye, hogyan lehetünk mi magunk hatással a dolgok jövốbeli fejlődésére.

\section{A káosztól a rendig}

Mindennek negatív aspektusa, hogy életünk számára elveszett minden, teljes mértékben adott, jelentéssel bíró kontextus - ez annak elkerülhetetlen eredménye, hogy a környezetünkhöz fűző természetes kapcsolatainktól elrugaszkodtunk a szabadság felé. E veszteség rendkívül fenyegető manapság, amikor gyökértelen energiáink rombolóvá válnak.

De számunkra létfontosságú, hogy ebben a szituációban egy másik lehetőséget is észrevegyünk. Ahol valaha számunkra automatikusan adottak voltak a környezô világhoz kötổ kapcsolataink, ott most már a mi felelôsségünk, hogy felfedezzük és ön- 
magunkból kiindulva megszójük ezeket a kapcsolatokat. Igen, a napi hírek, a nagyvárosok utcai zsivaja, nagyáruházak útvesztői, egy irodaház dolgozófülkéinek végtelenül rendezett sora, a mindenféle kulturális felületrôl ránk köszönó hirdetések özöne, az autók ablakán át látható, tovatûnố szétesett képek - mindez ostromol minket, reménytelenül széttöredezett, kontextusától megfosztott módon. De analógiában a teremtés ôsi mítoszával, talán tekinthetjük mindezt az összevisszaságot úgy, mint új „káoszt”, mely arra vár, hogy saját erőnkból rendet teremtsünk benne.

Ha az idôvel és a térrel már úgy kerülünk szembe, mint egységes matematikai elemek absztrakt gyújteményével, tehát alig találjuk magunkat teljesen belépve a pillanatba és a helybe, semmi sem akadályozhatja meg, hogy visszahelyezzük magunkat a pillanatba és a helybe, de most már tudatosan behozva a jelentés gazdagságát, melyért részben mi magunk is felelünk.

A vállalkozás nem lehetetlen. Az imént utaltam az információ tengerére, ,amely alig áll kapcsolatban az emberekkel, közösségekkel, és a hellyel, ahol élünk". De ez csak az elsố benyomás. Bármerre is nézünk, kapcsolatokat fedezhetünk fel. A kocsim által kibocsátott melegházhatást okozó gázok nem függetlenek a szibériai vadásztól, és a vadász küzdelme az utolsó megmaradt hóleopárdok egyikével, nem közömbös az „én” életem gazdagságára nézve. Minden összekapcsolódik; de ma már rajtunk múlik, hogy meghatározzuk és megvilágítsuk a kapcsolatok azon különös hálóját, mely kifejezi saját életünk sürgetô és önzetlen szükségletét.

\section{Az önkényesség veszélye}

Ez persze nem jelenti, hogy saját szövetünket önkényesen szőhetjük a jelentésból. Mi végső soron, magunk is a természet kifejezôdései vagyunk, és tudásunk, a legmagasabb szinten, a világ tudása önmagáról. Mikor magunkba tekintünk a jelentés forrását keresve, a világ belsejébe is tekintünk egyúttal, és vice versa. A természet „törvényei” vagy archetípusai jelen vannak a világban és a tudatunkban is - és a két helyszín nem olyan elkülönült, mint azt kartéziánus gondolkodásunk beidegzôdései feltételezik. Az a törvényszerűség és bölcsesség, mely kívülrôl formálta testünket ugyanaz a törvényszerúség és bölcsesség, mely most szerény, de növekvố arányban elérhetố számunkra belülrôl, amint (ha múveljük és felfogjuk azt) egyfajta fókuszponttá áll össze értelmezésünkben.

Mégis az önkényesség jelenti ma a döntố kockázatot. A virágzó „virtuális valóságokkal” kapcsolatos kérdés köztünk nem az, hogy „Ezek mûviek-e?” (a múalkotás és a múvészet az emberi tevékenység lényegi mozzanatai), hanem hogy „Relevánsak-e? Van-e mélyreható igazság bennük? Meglátjuk-e bennük a világ kreatív forrásainak továbbmutató és figyelemreméltó munkáját - megtanulunk-e „cselekedni a törvény szerint, melyben létrejöttünk" (J. R. R. Tolkien) - vagy ehelyett, pusztán azoknak a halott mechanikai lehetôségeknek kibomlását látjuk, melyeket gépeinkbe programoztunk?

Ehhez hasonlóan, nem rossz, ha szabadságot kapunk arra, hogy megformálhassuk saját identitásunkat online kontextusokban. Kérdéses, hogy komolyan vesszük-e a kihívást vagy komolytalan látszatmegoldásba menekülünk el előle. Egy dolog, hatással lenni egy csöndes, összeszedett viselkedésmódra, korlátozott, körültekintôen ki- 
választott, esetleg anonim elektronikus elfoglaltságokban, és más dolog leküzdeni az ember forrongó hangulatát a családi és munkahelyi feszültségek közepette. Mindanynyian nyertünk bizonyos szabadságot identitásunk megformálásában, de ennek egy komolyabb megfogalmazása azt mondja ki: felelôsséggel kell saját végzetünkön munkálkodni.

Ez már nem játék és szórakozás; ez egy életen át tartó küzdelem kemény munkája, verejtéke és néha könnyei, hogy túléljünk, illetve valami hasznosat tegyünk - ha online tevékenységek is (beleértve a szórakozást is) szolgálhatják céljainkat, annál jobb. De meg kellene értenünk: egy identitás kialakításán munkálkodni bármilyen igaz értelemben, annyi, mint kockára tenni életünk hátralevô részét e munka kedvéért.

\section{Egy szükséges irányváltás}

A probléma az, hogy miközben az elidegenedés, az elkülönülés, és az absztrakció technológiái megszabadíthatnak minket a világ kényszerítő erejétôl, nem vezetnek el minket a negatív megvalósításon túlra. Üresen hagynak - korlátoktól megszabadítva, de azoktól a tartalmaktól is megfosztva, melyekkel kitölthetnénk az ürt.

Ezenfelül az absztrakció folyamatai, megfelelő ellensúlyozás nélkül, gyorsan rabságba kényszerítenek, s sokkal radikálisabb értelemben, mint azt megelôzóen valaha is lehetséges volt. Feljebb azt mondtam, többé már nem élünk „benne” a pillanatban, részt véve minôségeiben, inkább arra törekszünk, hogy erôforrásként használjuk ki a pillanatot. Ez szabaddá tesz, de ha nem találjuk meg a módját, hogy - szabadságunk tudatában - újra belépjünk a pillanatba annak teljes mélységében, úgy azt találhatjuk, hogy nem is mi használjuk ki a pillanatot, hanem az használ ki minket. Sokan közülünk már tudnak valamit errôl a kockázatról.

Hasonlóképp, szóltam már arról a belső reflektáló térről, ahol szabadon alakíthatjuk ki új hipotéziseinket. De ha nem tudjuk meghaladni absztrakt és mechanikus gondolkodási szokásainkat, nem lesz képzelốerônk arra, hogy elgondoljuk a világ szemlélésének mélységesen új módjait.

Absztrakció, elidegenedés, és elkülönülés voltak talán szabadságunk előfeltételei, de maguk nem válthatják be e szabadság ígéretét. Ha elvágtak bennünket a világ jelentésétől, érzékeny minôségeitől és kifejező jelenlététôl, ránk marad, hogy élvezzük ennek a függetlenségnek a hasznát. És ez csak azt jelentheti: el kell kezdenünk visszakapcsolódni a világba - de most már a kapcsolat humanitás irányában elmozdított kezdeményezésével és középpontjával.

Ennek másik megfogalmazása, ha rámutatunk a magától értetődőre: ma, a különböző szélsőségeknek köszönhetôen, amelyekbe a világtól való elidegenedésünk juttatott minket, tudatosabbak lehetünk a világ szükségleteit illetôen, ezért nagyobb is a felelősségünk, hogy gondoskodjunk ezekről. De ezt nem tehetjük másképp, mint újra elkötelezve magunkat a világ mellett, leküzdve az elkötelezetlenség attitûdjét. Ez azt jelenti, hogy a világ „technologizálásának” hosszú története, ami boldogan elvezetett minket felelősségünk jelenlegi terhéig, lehet, hogy most a legfóbb akadálya lesz annak, hogy e felelősségnek megfeleljünk. 
De ha felismerjük az akadályt és megpróbáljuk leküzdeni, hálásak maradhatunk mindazért az ajándékért, amit az absztrakció technológiája hozott nekünk. Barfieldet parafrazálva (1965, 185-86. o.): ahol Augustinus Ádámon és a kiûzetésen elmélkedve, mély értelmúen így kiáltott fel:

„Szerencsés bün!”

mi napjainkban megtanulhatnánk kiáltani, éppily mély értelmúen:

„Szerencsés technológia!”

És ameddig ilyen szellemben tehetjük ezt, boldogan csatlakozom a technológia dicséretét zengố kórushoz.

Antos Balázs forditása 